\title{
A Cognitive Stylistic Approach to Narrative Shift in Prophet Ayyub's (Job) Qur'anic Story
}

\author{
Submitted by \\ Dina Ragab Muhammad Gassor \\ PhD Student
}

\begin{abstract}
The present study is intended as a guide for all Qur'an readers and listeners to show interest in understanding and studying the text of The Holy Quran. Arabic has always stood between researchers/readers/listeners and their full comprehension, their tools and their final product, due to its heavy grammar and formidably polysemous vocabulary.

Studies and research on Narrativity and Cognitive Stylistics have attracted the attention of many researchers in the field of the Qur'anic discourse. Most researches deal with the discourse of the Qur'an from either a stylistic view or a narrative one. However, no research has dealt with both, the cognitive stylistic view and the narrative view all together. The discourse of the Qur'an has its own structural nature since its grammar, lexicons and sounds are all specific to it. However, the purpose of each part of its discourse allows for certain interpretations and meanings. So, a special theoretical framework is used here to reflect the uniqueness of the Qur'an as a miraculous text book.

The present study examines the Qur'anic discourse by analyzing its prophetic stories. The study aims at identifying the Qur'anic narrative shift occurring in the Qur'anic discourse along with its form and function. It also aims at identifying the reasons why the Narrative Shift allows for the Qur'anic intertextuality by tracing the frequency of its occurrence inside the Qur'an. The study also investigates the relation between the Narrativity style of the Qur'an and its effectiveness and persuasiveness to its readers and listeners. It also examines the general and specific functions behind using the shift in the narrative progression.
\end{abstract}

Keywords:

Cognitive Stylistics, Qur'anic Discourse, Narrative, Intertextuality, Persuasion 


\section{مقاربة اسلوبية معرفية للتحول السردي في قصة التبي أيوب القرآنية}

المستخلص

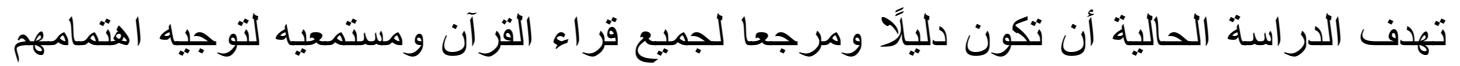

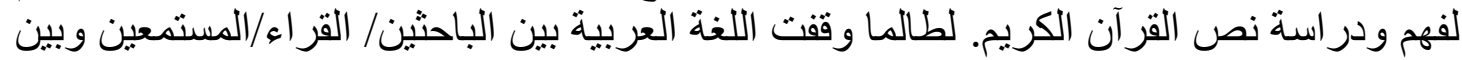

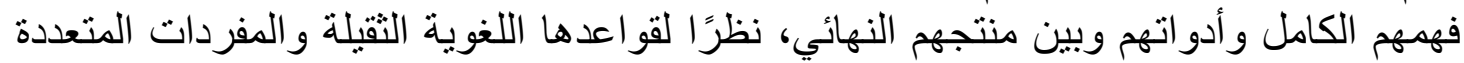
المعاني بشكل هائل. جذبت الدر اسات و الأبحاث حول السرد و الأسلوب المعرفي اهتمام العديد من الباحثين في مجال

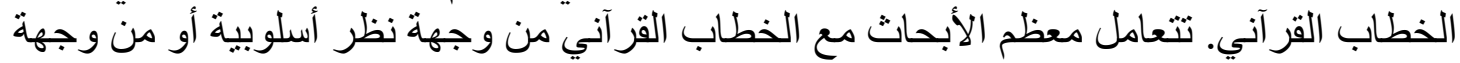

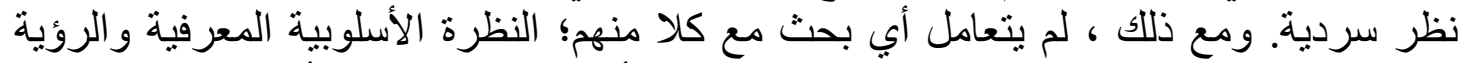

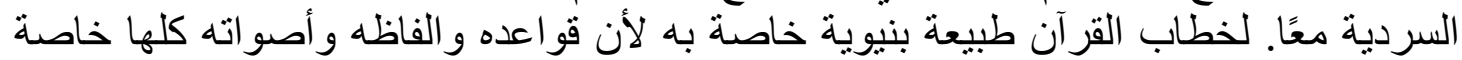

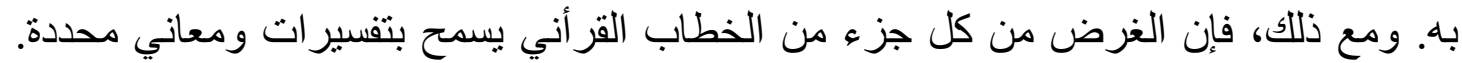

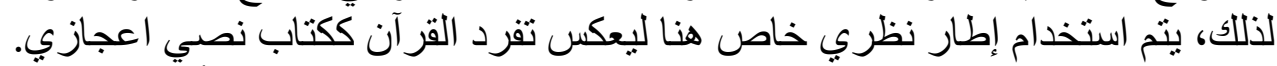

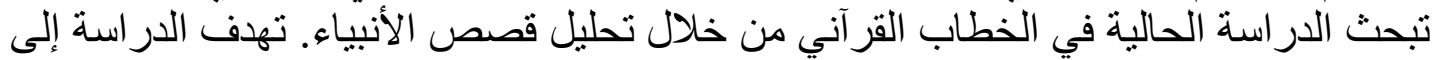

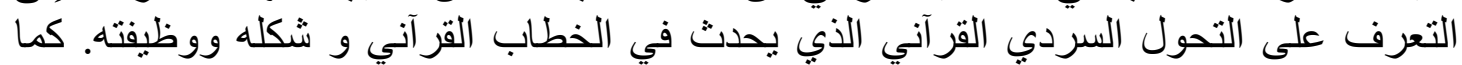

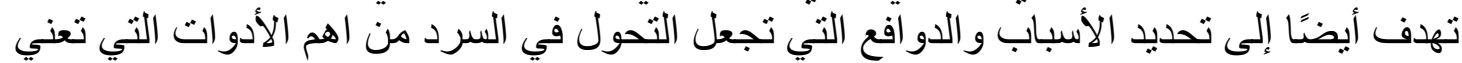

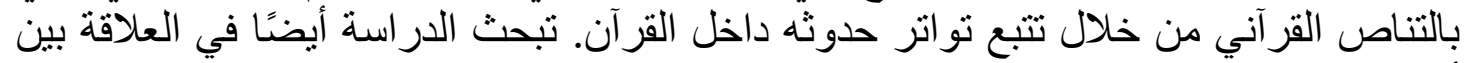

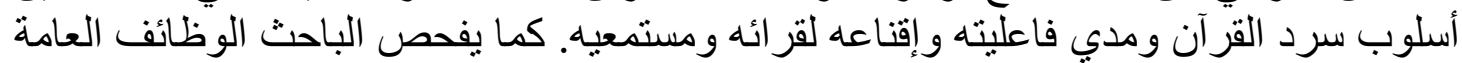
و الخاصة ور اء استخدام التحول في فئسود تطور السرد. 


\title{
A Cognitive Stylistic Approach to Narrative Shift in Prophet Ayyub's (Job) Qur'anic Story
}

\author{
Submitted by \\ Dina Ragab Muhammad Gassor \\ PhD Student
}

\section{Introduction}

The present study is meant to shed light on Qur'anic Narrative Shifts. The researcher uses the term Shift to refer to the alternation in narrating the same Qur'anic story. It examines the Quranic narratives from a lexico-grammatical stylistic perspective. Its primary goal is to reveal how far the analysis of Quranic narratives may help in the recognition of the specific features of both style and meaning of its text. An extensive discussion of the Qur'anic narratives serves as a background to the discussion of the relation between the lexico-grammatical strategies and the intertextuality of the Qur'anic text. The study also argues that the Qur'anic rhetoric and persuasion crucially rely on the lexico-grammatical features of its narrative. Finally, the study explains all these functions and relations by applying specific stylistic narrative theories on all the narrative shifts of prophets' Qur'anic stories.

\subsection{Context of the study}

The Qur'anic narrative is the main ground on which the study of Islamic religion has grown and still rests. Moreover, the flourishing of linguistics and disciplines studying religious texts, language, and narrative makes investigating Qur'anic narrative linguistic features part of our thinking, recollecting, imagining, explaining, and understanding the Qur'anic language.

The present study applies a lexico-grammatical analysis to understand the style of the Qur'anic narratives and analyze their linguistic features that lead the researcher to justify the significance of structuring the narratives in the way they are and should lead to better understanding of the Qur'anic narrative discourse.

\subsection{Objectives of the Study}

The present study is an attempt to analyze Qur'anic Narrative Shifts applying David Herman's Narrative-Starter-Kit (2007) to:

1. Explain the Qur'anic narrative style 
2. Highlight the narrative shifts in the Qur'an's narrative

3. Understand the Qur'an phenomenal linguistic miraculousness by showing the Qur'an's rhetoric, persuasiveness, and intertextuality

\subsection{Research Questions}

This research attempts to investigate one major question and two subsidiary ones:

1. What are the Narrative Shifts, their linguistic characteristics, and their function in the Qur'an?

a. How are the Qur'anic rhetoric and persuasive devices expressed on the lexico-grammatical level?

b. To what extent have the Narrative Shifts influenced the Qur'anic discourse's intertextuality?

\subsection{Significance of the Study}

The Qur'an has such a great value; it has presented itself as an important source of many branches of diverse sciences over ages. One of the most important aspects of it is its language. This study is meant to shed light on the Qur'anic interpretation in the light of its Narrative linguistic rhetoric. This study is an attempt to investigate the Qur'anic Narrative linguistic features and style. Due to the multifaceted features of the Qur'an, the study of its language and style is essential.

\subsection{Outline of the Study:}

The study begins with an introduction, scope of the study, objectives and research questions.

\section{Literature Review}

This section reviews the literature of the studies that dealt with Qur'anic narratives and narrative shifts. It also reviews the literature of the previous studies that applied Herman's Kit to Narratives.

\subsection{Qur'anic Narrative}

The classical exegetes' approaches were associated with studying the Qur'ānic narratives literal text. Theoretically, they assumed that the Qur'ān's literal meaning was prior to any exegesis and thus, represented a process rather than a result. They concluded that the Qur'anic narrative serves as a source of history and theology by recounting the historical and theological facts and situations that brought about that particular 


\section{Dina Ragab Muhammad Gassor}

situation. In short, they assumed that the main purpose of these Qur'ānic narratives was to preserve the history of previous prophets nations and their theological mission. (Troudi, 2011)

Sufi exegetes have maintained that the metaphorical and allegorical interpretation of the Qur'ān is the fundamental source of self-seeking knowledge. They insisted on discovering its deeper meanings to justify the Sufi worldview and find their ideas in these texts within an Islamic framework. These philosophical and mystical approaches allowed them to allegorize the Qur'anic narrative text and find its esoteric meanings that lie behind the literal ones. Therefore, for Sufis, these stories have become the central theme that reflects the general culture of early classical Sufi Islam. For instance, Sufi commentators considered that all Qur'anic narratives are humanly accessible and divinely mysterious. Their hermeneutical efforts differed from the traditional and rational tafsīrs because they applied their mystical and allegorical visions to the Qur'anic narrative texts.

For the Literary approach, it emphasized that the stories of the Qur'an are allegories, amthal, not intended to convey historical fact. The body of such stories may appear historical, but their message does not necessarily reflect history. Their claim's evidence is that Qura'n deliberately does not mention either time or location of historical incidents in its stories, and it also omits some characters. Also, in dealing with several historical stories the Qur'an selects some events and leaves out others and it changes chronological order of events. It occasionally switches the characters performing given actions. When the story is repeated in another chapter of the Qur'an, a character's dialogue may be different from that of the spoken one in a previous context. And it occasionally and chronologically adds later incidents to the narrative.

\subsection{Narrative Perspectives to Religious Studies}

It is important to mention at the outset that most of the Qur'anic scholars and exegetes, classical as well as modern, have provided glossaries, commentaries, and discussions on the function and use of narratives in the Qur'an. For example, Badr al-Din al-Zarkashi (1391) in al-Burhann fi 'Ulum al-Qur' an and Jalal al-Din al-Suyuti (1505)) in al-Itqann fi 'Ulum al- Qur'an have allocated separate sections on the discussion of narratives in the Qur'an (amthal al-Qur'an) with reference to Arabic rhetoric and the special significance of the Qur'an. In the same way, modern Qur'anic commentators like Amin Ahsan Islahi (1997) and Sayyid Qutb (1966) provide a detailed account of the use of narratives in their commentaries 
on the Qur'an. In addition, Abdul-Raof devotes a section of his "Exploring the Qur'an" to the Qur'anic narratives.

Scholars such as M. A. S. Abdel-Haleem; Issa J. Boullata; Mustansir Mir; Angelika Neuwirth; Andrew Rippin; John Wansbrough and Stefan Wild have conducted different studies on Qur'anic narratives. However, a specialised, rigorous and objective approach still resides in an embryonic and impressionistic state. This is due to the Qur'anic narrative linguistic nature that sometimes takes a non-narrative form.

Kermode (1979) discusses a number of significant points about the narrative nature of biblical narratives with reference to the New Testament, which could be applied to Qur'anic narratives as well. For example, he states that narratives reflect a range of senses which can be understood on a scale "at the one end of which is a zero point, a strong saying," without narrative content, and "at the other is the well-formed story" exhibiting "all the marks of narrativity." Some narratives are entirely transparent (that is, their meaning is clear) while others are very obscure and they mean different things to different people "mean more than they seem to say and they mean different things to different people, with a particularly sharp distinction drawn between those who are outside and those who are inside." (Kermode, p. 44)

Other scholars express similar ideas about biblical narratives though they do not seem to agree upon one single definition or explanation. Afsar (2005) conducts a basic survey of literature on narratives showing that there are certain characteristics shared by all parables, sacred or profane, in a range of different combinations. First, in a parable, there is usually a comparison between two apparently dissimilar things, objects, situations or persons. Secondly, a connecting word showing explicit comparison is used. For instance, words like "like" or "as" in English or their equivalents in other languages — hence "similitude" — are normally used. Thirdly, the objects of comparison are chosen from common, everyday life: such things as clouds, storm, lightning, thunder, gnat, fly, seed, tree, etc. Fourthly, there is usually a short narrative embedded, sometimes in an embryonic form, which is not meant to be taken only at face value. Fifthly, there is usually an aporia or gap in a parable which makes it susceptible to multiple and divergent interpretations. And finally, a parable is used for didactic purposes.

Kermode (1979) states that biblical narrative have a didactic purpose and they have double meanings, that is, one meaning for those who are "inside" - the believers, and the other for those who are "outside" - the unbelievers.

Asfar (2005) agrees with Kermode's view of biblical narratives and explains that in addition to incorporating the general characteristics of 


\section{Dina Ragab Muhammad Gassor}

narratives, the Qur'an seems to indicate deliberate intent about its use of them. It not only defends their use but also makes sure that they are not misunderstood or underestimated by readers. He adds that Qur'anic narratives are considered a good vehicle for teaching moral lessons of usually sublime and abstract nature in ordinary and concrete terms.

In the present study, the researcher deals with both Qur'anic narratives that have explicit narrative content as well as those that have strong implicit narrative elements.

\subsection{Conclusion}

This chapter has tried to provide a theoretical background regarding the tools used for the analysis. It reviewed most of the researches in stylistics and Qur'anic narrative. The next chapter gives an account of the methodology, information about the data, as well as the procedures of the analysis.

\section{Methodology}

This Section deals with sources of data, how data is selected for the study, and the procedures of data analysis. Moreover, it provides the research methods adopted and the reasons behind choosing them.

\subsection{Theoretical Background}

In the present study, the researcher employs a lexico-grammatical analysis following a miscellaneous approach by adopting a very significant cognitive stylistic model theory:

- David Herman's Narrative Starter-Kit (2007)

\section{(a) 3.1.1 Lexico-grammar}

It is a term peculiar to systemic functional linguistics. It was coined by Michael Halliday, the father of systemic functional linguistics, to describe the continuity between grammar and lexis. For many linguists, these phenomena are discrete. But Halliday brings them together with this term. As with other dimensions of Halliday's theory, he describes the relation between grammar and lexis as one of a 'cline', and therefore, one of 'delicacy'. In 1961, he wrote "The grammarian's dream is...to turn the whole of linguistic form into grammar, hoping to show that lexis can be defined as "the most delicate grammar"". (Halliday, 1961, p.267)

The researcher believes that lexico-grammatical analysis gives a full insight into how the narrative message is encoded via the medium of language, on the one hand, and how it is organized to achieve this, on the 
other. Also, it is a core guide in the process of reading and interpreting the narrative rhetoric.

\section{(b) 3.1.3 A Starter-Kit to Studying Narrative}

David Herman illustrated a 'starter kit' for the study of the narrative (2007). He perceives that the narrative core areas to be studied are:

- Story, Plot and Narration

- Time and Space

- Character

- Dialogue

- Focalization

- Genre

Story, Plot and Narration; whatever the narrative is about. All stories move only in one direction, forward through time, if there is a knowable beginning, that is where they begin, or if there is a knowable end, that is where they end. The process of telling is the story's narration. This distinction between story and narration is also important. It is an implicit acknowledgment that a story is understood as having a separate existence from its narration. As such, different narrators can tell it in different ways. The narration of any story can be different, with different words, different emotional inflections, different perspectives, and different details.

Time and Space are the basic categories of human orientation to the narrative world. Their compressions are frequent both in retrospective narration and in circular plot structures.

Temporal and spatial relationships are essential to our understanding of narratives and go beyond the specification of a date and a location. Information concerning the when and where of any narrative is important to our cultural understanding and to our response to actions, emotions, and morals. It is only part of a much wider network of temporal and spatial structures. Narratives unfold in time, and the past, present, and future of a given event or action affect our interpretation of that action, while the characters who populate narrative texts move around, inhabit and experience different spaces and locations, allowing readers to construct complex worlds in their minds. To read a narrative is to engage with an alternative world that has its own temporal and spatial structures. The rules that govern these structures may or may not resemble those of the readers' world. And while readers do not, on the whole, try to map out hierarchical relations between world levels in the way narratologists do, they nevertheless have a sense that narratives can be divided into different temporal and spatial zones. 


\section{Dina Ragab Muhammad Gassor}

In the widest sense, "character" designates any entity, individual or collective - normally human or human-like - introduced in a work of narrative fiction. Characters thus exist within storyworlds, and play a role, no matter how minor, in one or more of the states of affairs or events told about in the narrative. Character can be succinctly defined as storyworld participant. Now, for its part, the storyworld itself divides into the spheres of narration and of the narrated, the telling and what is told about. "Character" in the narrower sense is restricted to participants in the narrated domain, the narrative agents. Characters are introduced in the text by means of three kinds of referring expressions: proper names (including letters and numbers), definite descriptions, and personal pronouns. Names and definite descriptions occurring in a given work often originate with it, hence introducing original fictions, or occur already in earlier works by the same author or by others, thereby yielding new versions of the original fiction, or pick out an actual person, thus yielding a literary, sometimes highly fictionalized, version of the real individual.

Representing the voices of characters in a story is an effective way of enlivening a narrative. A vital aspect of how we remember and grow close to fictional characters is the way they speak: their accents and dialects place them geographically and socially, while their verbal idiosyncrasies and catchphrases help to make them memorable, even endearing. In an oral narrative, a change in intonation and/or pace may be sufficient to indicate to the listener where the narrator is quoting from another. The process is more complicated when it comes to written narratives, as the writer has to deal with the transition between one channel of communication and another. Nevertheless, the conventions for representing speech have become well established whether the context is a news story, a biography, or a novel, and readers rarely stop to question why speech is laid out as it is. As well as adding variety to a narrative, representing the speech of those who take part in a narrated event, or who are somehow qualified to comment on what takes place, may also contribute importantly to the authenticity and authority of the story. It is difficult to imagine a narrative that does not include some kind of representation of speech, but the extent to which this is foregrounded varies considerably. The degree of directness of the report may also vary, but in the present study, the researcher is concerned primarily with what has been termed direct or free direct speech, where the words of the characters appear to be reproduced verbatim and contribute significantly to the central action or plot.

If narratology - the structural theory and analysis of narrative texts - were to be divided into just two major parts, 
then narration and focalization would be very suitable candidates. Narration is the telling of a story in a way that simultaneously respects the needs and enlists the co-operation of its audience; focalization is the submission of (potentially limitless) narrative information to a perspectival filter. Contrary to the standard courtroom injunction to tell "the whole truth," no-one can, in fact, tell all. Practical reasons require speakers and writers to restrict information to the "right amount" - not too little, not too much, and if possible only what is relevant.

The characterization of a narrative is grounded in the notion of genre, it is the grouping of texts together on the basis of certain shared features. It suggests that relating a text to a genre may serve a number of different purposes. First, genre helps us to describe texts by singling out textual components worthy of attention such as plot structure; in turn, description helps us to classify a text by placing it among other similar texts. In this view, genres are principled groupings of texts. Second, genre directs the ways in which we read, and interpret texts. Without some shared conception of what, for example, a narrative is, readers are not aware of the narrative implied message. A genre functions as a norm or an expectation guiding readers in their encounter with texts. Third, genre prescribes artistic practices. Fourth, it also helps readers to evaluate what they read.

\subsection{Data and Data Processing}

The main sources of the present study are the Glorious Qur'an along with six different interpretations that focus mainly on the narration nature and the stylistic miraculousness of the Qur'an:

- Aj-Jurjani's, I'jaz al-Qur'an (1079)

- Az-Zamakhshari's, Al-Kashshaf (1195)

- Mahmud al-Alusi, Rūh al-Ma'ānī fĩ Tafsīiri-l-Qur'āni-l-'Az̄īm (1853)

- $\quad$ Said Okur I Nursî, Risale-i Nur (1950)

- Muhammad Rashid Rida, Tafsir al-Manar (1947)

- Ash-Sha'raawi's, Khawater Ash-shaarawi (1992)

The present study also deploys three different translations to the Qur'an as secondary resources, these specific translations are selected because they are of the most recent interpretations of the glorious script.:

- Towards Understanding the Ever-Glorious Qur'an (Muhammad Mahmoud Ghali, 2003) 
- The Qur'an: a New Translation (Muhammad Abdel-Haleem, 2004)

- The Gracious Quran Complete: A Modern Phrased Interpretation in English (Ahmad Zaki Hammad, 2008)

\subsection{Procedures of Data Analysis}

Data analysis is conducted by applying Herman's Narrative Starter Kit (2007). For deep and surface analysis, other studies such as Labov (1972), Short $(1989,1996)$, and Culpeper $(2001,2008)$ are applied.

Lakoff and Johnson (2003) explain that "Conceptual systems of cultures and religions are metaphorical in nature". In other words, "all the significant assertions of theology are expressed in language that is irreducibly metaphorical" (Avis, 1999: 90). Language that "is not assumed to be a representation of ideas" (Scott, 1988: 34) is not only an empire of signs, but also an empire of metaphors. In addition, "metaphors are iconic signs presenting meanings as well as representing meanings" (MacCormac, 1990: 192). Kövecses mentions (2002: 6) that metaphors typically use abstract concepts and assume that these concepts are physically concrete. Abstract concepts without metaphors are incomplete; furthermore, we complete our intellectual world through metaphor.

Not only the Qur'an but also the "whole of our universe is textual" (Barry, 2002: 35). In addition, texts are clues and they teach how to read the lives people live. "Texts, messages, and symbols never speak for themselves. They inform someone" (Krip-pendorff , 2004: 25).

According to Lakoff and Johnson (2003: 273), "we live our lives on the basis of inferences we derive via metaphor". They also say 'yes' to the question of "do you think the whole world is a metaphor for something?" (Skarmeta, 1987: 15-16). Each new metaphor shows a new dimension of realities in the world; therefore, each metaphor is a new discovery. To understand metaphors in our lives is to realise who we are and which society we live in.

\subsection{Conclusion}

This chapter has stated the data and the procedures of the data analysis. The next chapter covers the analysis of both plays.

\section{Analysis and Discussion}

The researcher employs Herman's Narrative Starter Kit (2007). 


\subsection{Prophet Ayyub's Story}

Prophet Ayyub's story is mentioned in the Holy Qur'an two times. As per Qur'anic scholars whose interpretations are adopted in this study, Ayyub, prior to his illness, was an extremely wealthy man. He possessed treasures of gold and silver, and he owned land, farms, fields, and cattle. He also had many children. Scholars add that the illness overtook him when he was seventy years old. The illness was so severe. Historians have written that not a single limb of Ayyub was free from disease except his tongue and his heart, which he used for the remembrance of Allah. He lost his children and his whole family except his wife who remained devoted to him.

Scholars have recorded different durations and the extent of the Prophet's illness. Some claimed his illness lasted three years, others claim seven years, and others claim eighteen years. Regardless of the exact number of years, Prophet Ayyub patiently bore his illness for a very long time. Never did Prophet Ayyub lament, grow angry, or reject the fate which Allah had decreed for him. Day and night, throughout the pain and difficult times, Prophet Ayyub would always praise Allah. That is why all Ayyub's prayers were accepted.

That is why Qur'an narrates the story of prophet Ayyub, peace be upon him, as an example in patience; Ayyub's verses are exposed to the afflictions that faced his life; his body, his money, and his son. The verses narrate the story of his patience, his turning into Allah, and his faithful dedicated prayers.

Hereinafter are the two different narratives narrating Prophet Ayyub's story. Although they both tell a story about the same person, Prophet Ayyub, they still differ in many aspects. They both come in a different position in the Qur'anic book, they both differ in the amount of what they say/not say, and they both differ in how they say it. This all result in different interpretations and explanations to the same story. These changes that took place are what the researcher believes to be a shift in the narrative, a Narrative Shift.

\begin{tabular}{|c|c|}
\hline \multicolumn{2}{|c|}{ Narrative (1) } \\
\hline Al-Anbiya (The Prophets) 83-84 & الأنبياء \\
\hline 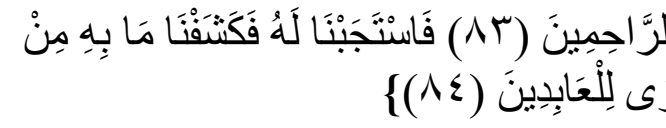 & 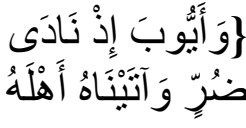 \\
\hline
\end{tabular}


again with no details on how Allah answered the prayers and it is not clear what is the process by which he got his family and people back. The main focus is Allah's fulfillment to prayers. This all is accepted in form and function as the narrative is cited in the Qur'anic chapter (The Prophets) that deals with the issue of "faith". It does so under three main headings: namely, Allah's oneness, His message, and mankind's resurrection. The flow of the chapter deals with its subject matter, to refer to a number of great universal prophetic phenomena and linking them with the concept of faith. The verse does not reveal any appealing for his condition to be changed nor does it suggest anything to be done. Thus, it reflects an attitude of perfect humility before Allah. Ayyub here is pَesented as a model servant expressing his pure submission " وَأَنتَ أَرْحَمُ الرَّاحِيِينَ/and You are The Most Merciful of the merciful."

As Ash-Sha'raawi explains, Ayyub was being tested with hardship; in this particular instance, the chapter mentions Ayyub's supplication and Allah's response, because the overall atmosphere of the chapter is one of grace bestowed from on high on His prophets and the care He takes of them when He tests them. Ayyub's prayer, as mentioned here, does not go beyond describing his condition and emphasizing Allah's attributes.

The verse then is continued with "فَ'/We responded" revealing the fact that Ayyub's personal affliction was removed, and his health was restored due to his pure believe in Allah. This verse is also a reminder to all the believers; a verse by which believers are guided indirectly through their faith journey. The test to which Ayyub is put provides an example in faith, and his patient endurance sets a model for all to follow. The use of “لألْعَاِِِينَ/who worship Us" within the context of hard tests has and reveals all the significant messages. Believers may be subjected to tests and hardship. This is the time when faith and total submission to Allah are the key to salvation. Such stress on the relation between faith and Allah's answer makes it inevitable for readers to be part of the believers' crowd. They tend to always be part of the good faithful party whom prayers are always accepted.

Author's choice "to redistribute the order in which the story events are told is a plot decision. [...] it brings us in to a situation that is clearly charged with story, with only the tiniest scraps to indicate what the story is." (Abbott 2018). While Narrative (1) has a managed plot that creates a sense of curiosity, that in turn generates readers' feelings to know the story. Narrative (2) starts at Ayyub's call too, but it rather gives more information and details about prophet Ayyub and his distress which adds a feeling of pleasure to readers. Abbott (2018), writes "Just as a story can be narrated in different ways, so it can be plotted in different ways". Narrative (1) narrates a past story of faith; the greater the faith, the more 


\section{Dina Ragab Muhammad Gassor}

vigorous is the response. Narrative (2) is full of imperative verbs whether

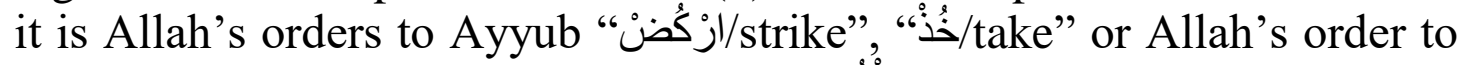

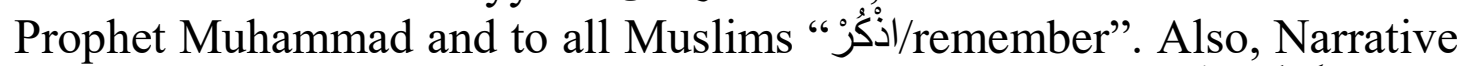
(2) gives more details about the distress Ayyub faced " مَسَّنِيَ الثنَيَّطَانُ بِنُصنبِ اوَ عَذَابٍ Shaitan (Satan) has touched me with distress" and the process by

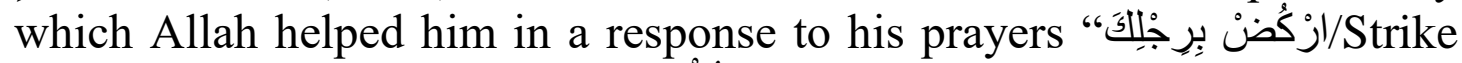
the ground with your foot" "وَخُذْ بِيَِكَكَ'take in your hand”. All these new information - evil's distress touch as opposed to Allah's power - leads to a new interpretation that is mainly under the umbrella of submission.

As Ash-Sha'raawi claims, in this narrative, Ayyub complains to Allah about the troubles Satan's schemes and whispers are causing him. But once Ayyub proves his sincerity beyond any doubt, and once he has rejected all Satan's attempts to weaken him, Allah answers all the prayers, ending the whole test, and restoring his health. In this verse Allah gives clear and specific orders to Ayyub; He orders him to hit the ground with his leg, and once a cool spring is gushed forth, he would use it to get washed and he will drink from its water. This is all for him to recover his health.

Ash-Sha'raawi adds that the Qur'anic narrative here means that when his health was restored, he regained his family that had almost been lost to him. He also gave him more as additional favors. This serves as a reminder to those who have insight and understanding. What is important in the stories related to this chapter (Sad) is that they show how Allah bestows favors and grace on His servants. Although He subjects them to tests, they remain patient in adversity, bearing their hardship with assured resignation, knowing that whatever Allah decides is ultimately good. Such care and blessings were in return for what Allah knew of Ayyub's patience in adversity, his being a model of obedience, always turning to Him for support.

In that sense, readers will want to see themselves as the verse suggests, true models of obedience and patience. That is how faith is triggered and patience is learned, through putting themselves in Ayyub's shoes, they would learn and know that Allah's support has to be earned and that it is not just a gift.

Thus, the context of this narrative too is different as it is cited in the Qur'anic chapter ( $\mathrm{Sad}$ ) that speaks of oneness, acquiescence, revelation, and retribution. It also refers to the duties required by faith and acquiescence, which tests people'strue metal. Acquiescence is, then, the chapter's central theme describing some of the impediments and tests that always confront believers in their journey to acquiescence and oneness.

Hence, the repetition of the same prophet's story events but with two different plots and narrative styles is what the present study identifies as a 
narrative shift. This narrative shift is a remarkable feat of restructuring; closing all of the narrative gaps on almost every level; moral, psychological and metaphysical.

For Bridgeman, plot can be conceived as a "metaphorical network of paths", which either "converge or diverge", of "goals" which are either "reached or blocked". Thus, both Ayyub's cry for help and Allah's answer trigger a "reached" goal for Ayyub with a "converged" path for his family and people too. While they trigger a blocked goal for the disbelievers diverging from the right path, Allah's path.

\section{(ii) 4.1.2 Time and Space}

Bridgeman (2018) discusses that time and space are not just background elements in narrative; but rather part of its fabric, affecting readers basic understanding of any narrative. She adds that temporality is an important part of the effect of the text. That is why Genette suggested areas in which "temporal relationships" result in important comprehensive effects. These areas are "order", "duration", and "frequency", they add significant implications in discussing the relationships between story and discourse. (Bridgeman, 2018)

Again, these two narratives have a shift in their order and duration. Narrative (1) has four different times. Firstly, the time when Ayyub prayed and called for Allah's help. Secondly, the distress time; the cause of the prayer. Thirdly, the time when Allah answered Ayyub's call. Finally, the time when Ayyub's family and people returned back with him. For Narrative (2), there are five times. Firstly, the time when Ayyub prayed for help. Secondly, the time Satan touched Ayyub; the cause of the prayer. Thirdly, the time of Allah's answer presented in Him asking Ayyub to strike for the spring and to drink some of its water. Fourthly, the time Ayyub got his family back; which comes in-between the strike of the spring and Ayyub taking the water. And finally, the time Allah asked him to take the rushes in his hands. In fact, there is no much detail about the significance of these two narrative's timing found in the Qur'anic interpretations. However, it can be related to the flow of their chapters.

For Narrative (1), according to Ash-Sha'raawi the flow of the chapter AlAnbiya (the prophets) deals with the issue of faith in Allah. It concentrates believers' attention on the unity of the creator, Allah, and His controlling powers. Time in Al-Anbiya verses (41-44) is limited and briefed revealing the faith of prophet Ayyub and Allah's care of him. That is why the limitation in the timing of Narrative (1) is seen to reveal how short the path between Allah and his true believers. Just surrender 


\section{Dina Ragab Muhammad Gassor}

everything to Allah as prophets always do, and here $\mathrm{He}$ is to answer without any shred of doubt with his power over all things.

For the space of narrative (1) does not specify any specific spaces. It does not show where exactly prophet Ayyub is staying or where he was praying. Also, it is not said whether the space is changed after the prayers are answered. This again adds to the same concept and topic of the chapter itself and to what the time of this narrative means. Allah is here and there, $\mathrm{He}$ is in everywhere, just have faith.

On the other hand, Narrative (2) does not limit the time. As AshSha'raawi believes, Șād chapter is about submission and oneness; in that sense, the narrative states Allah's orders for Ayyub for his distress to be ended. The orders are stated in a sequenced series of events drawing an image of Ayyub following Allah's orders to get rid of the distress. So, for Ayyub to reach Allah's answer, there is a path of orders to be followed. This again, if relates to the chapter's theme, reveals that Allah's answer is true only when his word and orders are followed. This reveals the concept of patience, be patient, surrender and follow Allah, and He will answer. For the space, there is no specification of space in this narrative. The core and stress is not on the where, it is on the who, how, and when.

There are also other shifts in time and space for these two narratives. The exact time and space Allah conveyed them to Prophet Muhammad PBUH. This might not add to the interpretation of the narrative itself, but they surely add to the background information of why this story is conveyed the way it is, and why each of the narratives is located in its specific chapter.

Genette in her Narrative Discourse suggests three main areas that can produce an interesting effect on stories' discourse. One that relates to events' order, one to events' duration, and one concerning how often an event occurs; frequency. Sternberg explains that this affects readers' perception to the different temporal patterns and raise their curiosity. This is seen through the gap between what they have been told of the past and what else they imagine might have happened. (Bridgeman, 2018)

The frequency and duration of both these two narratives are crucial to the experience of the story. And as mentioned earlier, these two narratives shift in the number of events mentioned; Narrative (2) reveals more information about Allah's answer giving more length to that answer duration. This shift helps in revealing new facts about Ayyub's life (length of his distress and patience towards it). Reading Narrative (2) place emphasis on looking back and re-evaluating Narrative (1) in its light. It reveals how patience is significant in Ayyub's story and how Allah's answer was a result of an insistent serenity and tolerated perseverance. Repeating the same story in these two narratives is what the 
frequency area is about. The frequency in here undermines a dramatic impact by re-narrating Ayyub's cry in the light of Allah's orders and commands.

For the duration, on one hand, Narrative (1) is shorter in its length, revealing the simplicity and shortness of sufferings when there is faith in their creator. On the other hand, Narrative (2) is longer with new details and more information. This longer length helps emphasizing the concepts of patience and continued pursuit. Again, reading these two narratives in the light of each other helps in filling the gaps of meaning. In other words, faith is easy and simple, when there is patience and obedience.

Some spatial elements of bodily experience such as (up/down, near/far, inside/outside) have been proposed by many cognitive theorists to explain how space is constructed in any narrative and in turn, abstractly in readers' minds.

For the spaces, the researcher makes a more specific look at how readers can be positioned in the narrative. In these two narratives, there is the no traces on where is Ayyub nor his family and people. But a very

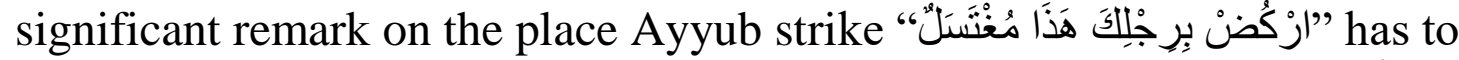
be made here. In the same sense, the readers' climax experience of " بحَارِد" adds to their special experience. Maybe the narrative interest in not mentioning any spaces eases the path for readers to experience it in their real world. But mentioning that specific place 'where Ayuub where cured' is for the special experience of readers. As Bridgeman suggests readers tend to imagine and shift from their real world to locations in the narrative world. In this view, these two narratives direct readers unconsciously to be part of Ayyub's life. The distress is real and it is part of each and every human life. But where ever they are, Allah's hand is always there. This is easy when there is no specific space is mentioned, giving readers the chance to imagine and draw whatever space they are comfortable to be in. They may even imagine themselves in washing in Ayyub's a spring of water. This all is conveyed by how these two verses opened and closed. The distress and the salvation. Sternberg emphasis this saying "Beginnings are where we first encounter the narrative world and establish its key characteristics. And endings are where we move towards our final"

This unconscious positioning cannot be done without being part of the narrative. And being part means characterizing oneself as one of/from the character(s). This is so easy when the concept of space is unclear. Readers here tend to merge their real space with that of the narrative; picturing themselves as part of the believers, picturing themselves as Ayyub himself other times. This is justified by Bridgeman in a very related and significant way as follows: 
In our own worlds, we are physically confined to our bodily experience of the world, but we have the ability to shift this experiencing center to imagine ourselves in other people'splaces, and in other locations. This ability is constantly utilized in the immersive activity of reading narrative fiction as we shift conceptually from our own reader-centered position to locations in the storyworld.

(Bridgeman, 2018)

\section{(iii) -4.1.3 Character}

As Margolin explains "characters are invented and generated in particular cultural and historical circumstances through the use of language $[\ldots]$ They are creatures of the word, and it is the socially and culturally defined act of fictional storytelling that constitutes and defines them". A story can be told in different ways by different narrators. The narration of any story would be different, with different words, different emotional inflections, different perspectives, and different details. These narrators might even contradict each other. Genette identified homodiegetic narrators as "those who are also characters in the storyworld (or diegesis) and therefore necessarily closer to the action" they tend to have greater reliability, inspiring more confidence in the information and views they convey Some heterodiegetic narrators have clearly developed personalities, refer to themselves in the first person. (Bridgeman, 2018)

Characters of Narrative (1) are, on the one hand, Allah, Prophet Ayyub, his family and believers, and on the other hand Allah to Prophet Muhammad narrating past events. While on Narrative (2), the devil appears to be one of the main characters affecting and playing main role in the story.

As long as written by the same author, narrative characters can be detached from their text or storyworld(s) and get exported across texts and world boundaries. This is based on the existence of core properties ascribed to the figure(s) in all of the narratives in which it occurs and considered essential. "To exist in our culture, readers form in their minds text-based images of characters, which they make available to others by talking or writing about them". (Margolin, 2018)

In the light of the above, messengers, followers, believers, praying people, etc. can all be triggered in the Qur'anic narratives as characters having the same qualifications and properties. In addition, when related to the readers' outer world, they affect their own beliefs and intentions stressing their audacity to be part of the winning group. Therefore, Ayyub 
and his family win over the distress in Narrative (1). And again, they win over the devil in Narrative (2). The winning in both the narratives is attached to having faith in Allah and being patient in front of His tests. That is why readers will always want to follow the same steps winners in the narratives took. Readers in that sense get turned into believers and followers instead of being just receivers.

\section{(iv) 4.1.4 Dialogue}

"A vital aspect of how we remember and grow close to fictional characters is the way they speak". One of the main characterizing features is dialogue. What characters say and how they interact with each other in a narrative. (Thomas, 2018)

Since all the chapters of the Qur'an include a huge number of narratives of past events, representation of speech is taking a huge part in it. Both these narratives are a representation of Prophet Ayyub's story by Allah to Prophet Muhammad, along with Allah's speech.

In Narrative (1), Ayyub is being reported in speech by Allah. The reported dialogue is between Ayyub, the prophet, and Allah. Revealing how Allah fast reply and answer his followers and believers. For Narrative (2), the verses tend to narrate the series of events that is both the reason and cause why Allah answered Ayyub. This gives the reader an understanding of the relations inside the narrative; Allah's paths of peace, surrender, and submission versus devil's disquietude and distress.

\section{(v) 4.1.5 Focalization}

As introduces by Genette, focalization is the submission of narrative information to a perspectival filter; a very basic and simple definition of this word can be that 'Focalization' concerns itself with the analysis of point of view/ perspective in a narrative text.

Genette defines a 3-term typology for focalization:

The first term corresponds to what English-language criticism calls the narrative with omniscient narrator, $[. .$.$] which is symbolized by$ the formula Narrator $>$ Character (where the narrator knows more than the character, or more exactly says more than any of the characters knows). In the second term, Narrator $=$ Character (the narrator says only what a given character knows); this is the narrative with 'point of view', or with 'restricted field'. [...] In the third term, Narrator < Character (the narrator says less than the character knows); this is the 'objective' or 'behaviourist' narrative. (p. 89) 


\section{Dina Ragab Muhammad Gassor}

In these two narratives, only information relevant to the chapter's theme is narrated; as a vehicle for conveying a centered vision for the whole chapter. This vision is realized in relation to its narrator that sees and that which is seen during the reading. This relation in these two narratives is "internal" since focalization is associated with Allah, who is one of the main characters in both the narratives. This is why the reader reads and sees the story accepting the view presented by the narrator participating in it, who, for Genette, is the narrative author. (Genette, 1980) (See 4.1.1.3) This is why the shift in these narratives is based on the knowledge of one of them as a background to the other, and this is how their perspective is rendered through the reading process. (See 4.1.1.1 \& 4.1.1.2)

On one hand, Narrative (1) is cited in the The Prophets chapter, Al-Alusi explains that in this chapter topics are revealed through mentioning brief stories about Prophets' distresses and Allah's prodigies upon them. On the other hand, Narrative (2) is cited in the Sad chapter. Nursî believes that this chapter tends to discuss its themes through Prophets' stories of patience through Allah's test.

\section{(vi) 4.1.6 Genre}

Scholars of the Arabic language and scholars of Islam have argued that the genre of the Qur'an is the genre of (ijaz). Still, Qur'an is a holy book that involves narratives, historical events, along with ethical and legal subjects, its genre as only a holly religious book limits its interpretations and stories to its specific religion. That is why the present study categorizes each narrative genre on its own, in relation to the Qur'an religious genre.

Applying that perspective to the Qur'anic narratives' interpretation, these two narratives deal with the same historical event, using and focalizing different plots, for a different moral each time. Therefore, they are treated as moral historical narratives in relation to their chapters' topic.

On one hand, Narrative (1) deals with the issue of faith by to refer to "the distress", a universal issue, and linking it with faith of prophet Ayyub who is saved. The point of this is that faith is part of the universal structure, and this is applied to any phenomenon, whether physical or psychological. This narrative illustrates and confirms that Allah's grace is a place of refuge into which Allah admits whomever He wills so that they find peace, comfort, and blessings. It illustrates the fact that prophets are beings no different from any ordinary humans, and are subjected to all human experiences from birth to death. (Ash-Sha'raawi)

On the other hand, Narrative (2) deals with submission, which are all duties required by faith, belief, and religious oppression. This is revealed 
by Ayyub's patience and obedience for his quest to be fulfilled. This is done in this narrative in relation to the chapter's main theme, describing some of the impediments and tests that confronted Ayyub and the appropriation of Allah's orders and timing. This all happened in the sense that patience and obedience are what characterizes strong believers. Narrative (2) conveys that Allah's mercy would never he shown to those so weak (Ash-Sha'raawi)

These interpretations of the two narratives cannot be rendered unless seen as a part of the whole Qur'anic Genre, the "ijaz" genre.

\subsection{Conclusion}

This chapter has displayed the data of the study. It has analyzed the data and exhibited the results.

\section{Conclusion}

The present study analyzed the Narrative Shift in Prophet Ayyub's Qur'anic story as a representative sample of the Narrative Shift in the Qur'an's narrative discourse. This chapter aims to summarize the findings of the analysis to find out to what extent the analysis findings give answers to the research questions raised in the introduction.

\subsection{Narrative Shift Form and Function}

- What are the Narrative Shifts, their linguistic characteristics, and their function in the Qur'an?

The main question raised in the present study is "What are the Narrative Shifts, their linguistic characteristics, and their function in the Qur'an?" As already discussed, and explained under the macro analysis, micro analysis, and the analysis discussion sections. Narrative Shift is a shift that occurs in the narration process on one or more than one level as a remarkable feat of restructuring and reconstructing the narrative. It allows closing all of the narrative gaps on almost every level; moral, psychological and metaphysical.

\subsection{Lexico-Grammatic Devices of Rhetoric and Persuasive}

- How are the Qur'anic rhetoric and persuasive devices expressed on the lexico-grammatical level?

Structurally, Arabic is identified to be a figurative language. It employs all the possible lexico-grammatic devices to affect readers/listeners perceptions to the many themes discussed under its biggest umbrella; the Islamic Religious Belief. So, to distribute faith, oneness, advocacy, etc. 


\section{Dina Ragab Muhammad Gassor}

this has to be firmed figuratively through the only discourse to which all Muslims would avail themselves.

4.3 Narrative Shift and The Qur'anic Discourse

- To what extent have the Narrative Shifts influenced the Qur'anic discourse's intertextuality?

Without a Narrative Shift as a Qur'anic discoursal feature, many of the intertextual elements would have been missing from the Qur'an. Shifting a narrative to its appropriate contextual purpose is what has been discussed in the present study for readers to perceive why a story is narrated through many different yet correlated narrations appointing different yet connected plots. 


\section{References}

Abbott, H. P. (2007). Story, plot, and narration. In D. Herman (Ed.), The Cambridge Companion to Narrative (pp. 39-51). chapter, Cambridge: Cambridge University Press.

Abdul-Raof, H. (2003). Exploring the Qur'an. Dundee: Al-Maktoum Institute Academic Press.

Afsar, Ayaz. (2009) "A Comparative Study of the Art of Jonah/Yūnus Narrative in the Bible and the Qur'ān." Islamic Studies 48/3: 319-339.

Al Fayad, M.G. (1995). Parables in The Glorious Qur'an. Riyadh, RY: International Islamic Publishing House.

Al Shaarawy, M. 1997. Tafsir al-Sharawi. Cairo: Akhbar El Yom Press.

Bradford, R. (1997). Stylistics. London and New York: Routledge.

Bridgeman, T. (2007). Time and space. In D. Herman (Ed.), The Cambridge Companion to Narrative (pp. 52-65). chapter, Cambridge: Cambridge University Press.

Browne, H. (2007). World history (2) 1900 - 2005. London: Cambridge University Press.

Cooper, B. (2010). Resurgent Spirits, Catholic, Echoes of Igbo and Petals of Purple: The Syncretised World of Chimamanda Ngozi Adichie's Purple Hibiscus in New Novels in African Literature Today. Ernest N. Emenyonu (ed).Rochester James Currey.

Cowie, A. P. (ed) (1989). Oxford Advanced Learners Dictionary of Current English 4th ed. Oxford: OUP

Crystal, D. \& Davy. (1969). Investigating English Style. London: Longman.

Deilami A, Azerbaijani M. 2002. Islamic ethics, eleventh edition, Islamic publications. Qom, Iran

Emmott, C. (1997) Narrative Comprehension: A discourse perspective. Oxford: OUP

Enkivist, N. et al (1978). On Defining Style: In Linguistics and Style. Oxford: OUP.

Fadlallah MH. 2005. steps in teaching, translation by Ahmed Beheshti, First Edition, published by Amir Kabir, Tehran, Iran

Fowler, R. (1996). Linguistic Criticism, 2nd edition. Cambridge: Cambridge University Press.

Genette, G. (1983). Narrative Discourse: An Essay in Method, translated by Jane E. Lewin. New York: Cornell University Press.

Halliday, M. A. (1978). Language as Social Semiotic: The Social Interpretation of Language and Meaning. London: Edward Arnold.

Heather, H. (2005). Coming of Age: Chimamanda Ngozi Adichie and the Voice of the Third Generation. English in Africa, 32 (1), 73.

Herman, D. (Ed.). (2007). Studying narrative fiction: a starter-kit. In The Cambridge Companion to Narrative. chapter, Cambridge: Cambridge University Press.

Hoover, D. (1999). Language and Style in the Inheritors. LanHam, MD: UP of America. 


\section{Dina Ragab Muhammad Gassor}

Ibn Abi al-Hadid, A-H. 2007. Hijri Ghamari, Nahj-Albelagha description, second edition, Darahya' Al Altras Al-Arabi. Beirut,lobnan

Jahn, M. (2007). Focalization. In D. Herman (Ed.), The Cambridge Companion to Narrative (pp. 94-108). chapter, Cambridge: Cambridge University Press.

Kadenge, E .(1982). Deviation and Foregrounding in chosen Swahili Literary texts. Unpublished M. A. Thesis. University of Nairobi.

Kermode, F. (1979). The Genesis of Secrecy: On the Interpretation of Narrative. London: Harvard University Press.

Kiguru, D. (2012). Violence in Childhood Narratives: Chimamanda Adichie's Purple Hibiscus and Half of a Yellow Sun. Unpublished M.A. Thesis. University of Nairobi.

Leech, G. \& Short, M. (2007). Style in fiction. Harlow: Pearson Education Limited.

Marefat MH. 2001. Hijri Ghamari, Talkhis Al-Tamhid, fourth edition, Islamic Publications Bureau. Qom,Iran

Marefat MH. 2005 a criticism on doubts about Quran, translated by Hassan Hakim Bashi, first edition, Tamhid cultural institute. Qom,Iran

Margolin, U. (2007). Character. In D. Herman (Ed.), The Cambridge Companion to Narrative (pp. 66-79). chapter, Cambridge: Cambridge University Press.

Matthews, P. H. (2007). The concise Oxford dictionary of linguistics. Oxford: Oxford University Press.

McIntyre, D. (2006) Point of View in Plays. Amsterdam and Philadelphia: John Benjamins Publishing Company

McIntyre, D. and Busse, B. (eds) (2010) Language and Style. Basingstoke: Palgrave Macmillan

Mikov, G. (2003). Linguistic stylistics. Nitra: Filozofick Faculta Univerzita Kontantna Filozofa.

Motahari M.1982. HosseinEpic, Tenth edition, Sadra., Qom,Iran

Motavalli K. 2005. public opinion and persuasion techniques, printing, Behjat Press, Tehran, Iran

Moradi H. 2010. of persuasion and communication, second edition, Saghi publication. Tehran,Iran

Ofeimum, O. (1988). Kole Omotoso, Ogunbiyi, Y. Ed. Perspectives on Nigerian literature: 1700 to the present Vol 2. Lagos: Guardian Books Nigeria Ltd. 185 -194.

Olateju, M. (2004). Discourse analysis. Ife: Obafemi Awolowo University Press.

Omotoso, K. (1988). Just before dawn. Ibadan: Spectrum Books.

Pratkanys A, Aronson E. 2005. Propaganda Age, translated by Kavous Sayed Imam Sadegh Abbasi, fourth edition, Soroush Press. Tehran,Iran

Pyrhönen, H. (2007). Genre. In D. Herman (Ed.), The Cambridge Companion to Narrative (pp. 109-124). chapter, Cambridge: Cambridge University Press. 
Sarookhani B. 2004. Persuasion as the Aim of communication, Social Science Quarterly, No. 23, Page 115, Tehran University,Iran

Semino, E. and Short, M. (2004) Corpus Stylistics: Speech Writing and Thought Presentation in a Corpus of English Writing. London: Routledge

Semino, E., Short, M. and Wynne, M. (1999) Hypothetical Words and Thoughts in Contemporary British Narratives. Narrative, 7 (3), 307-333

Sharif R. 1985. Hijri Ghamari, Talkhis Albayan fi Mojazat Al-Quran, Alamol Ketab, Beirut,lobnan

Shaker MK. 2003. Principles and methods of interpretation, first edition, the center of global Islamic sciences. Qom,Iran

Short, M. (1996) Exploring the Language of Poems, Plays and Prose. London and New York: Longman

Simpson, P. (2004). Stylistics. London and New York: Routledge

Syooty J. 2002. Alatqan fi al Oloom Alghoran, translated by Mehdi Haeri Ghazvini, Fifth Edition, Amir Kabir Publications Tehran,Iran

Simpson, P. (1993) Language, Ideology and Point of View. London and New York: Routledge

Stockwell, P. (2002) Cognitive Poetics: An Introduction. London: Routledge

Thomas, B. (2007). Dialogue. In D. Herman (Ed.), The Cambridge Companion to Narrative (pp. 80-93). chapter, Cambridge: Cambridge University Press

Thompson, G. (2004) Introducing Functional Grammar (2nd ed.). London: Arnold

Troudi, K. (2011) Qur'ānic Hermeneutics with Reference to Narratives: A Study in Classical Exegetical Traditions. University of Exeter.

Ufot, B. (2006). An introduction to practical stylistics. Lagos: Solar Flares Communications.

Uspensky, B. (1973) A Poetics of Composition, trans V. Zavarin and S.Wittig, Berkely: University of California Press

Wales, K. (2011). A dictionary of stylistics. Harlow: Pearson Longman.

Widdowson, H. G. (1975). Stylistics and the teaching of literature London: Longman. 